\title{
Formulation and characterization of norethisterone transdermal patch as an alternative route to oral administration
}

\author{
Ümit Gönüllü*, Dilek Şaki \\ Department of Pharmaceutical Technology, Faculty of Pharmacy, Istanbul University, Beyazit, Istanbul 34116, Turkey
}

${ }^{*}$ For correspondence: Email: ecz_gonullu@yahoo.com; Tel: +90 212 4400000; Fax: +90 2124400252

Sent for review: 27 July 2017

Revised accepted: 22 November 2017

\begin{abstract}
Purpose: To design a transdermal norethisterone (NE) patch for controlled drug release Methods: Polymers, viz, sodium salt of carboxymethyl cellulose (CMCNa) and hydroxyethyl cellulose (HEC), as well as a plasticizer (propylene glycole, $P G$ ) were used at various ratios to prepare NE films. The drug was dispersed in water and mixed with the polymer gel/plasticizer mixture prior to film casting. Weight variation, thickness, tensile strength, and the interaction between drug and film excipient were evaluated. The films were also characterized by Fourier transform infrared spectroscopy (FT-IR). In vitro drug dissolution and release from the transdermal patches (coded $C-L, C-T, H-L$ and $H-T$ ) were evaluated.

Results: There was significant difference between the batches in terms of in vitro drug release $(p>$ 0.05). Dissolved drug was significantly higher in $H-T$ film when compared to $C-L$ film $(p<0.05)$. In addition, drug release was significantly higher from $H-T$ patch than from $C-L$ patch $(p<0.05)$.

Conclusion: NE transdermal patches containing HEC and Transcuto@ have been successfully formulated. They can potentially be used to deliver NE via transdermal route to decrease the side effects associated with the oral route of administration of the hormone.
\end{abstract}

Keywords: Norethisterone, Transdermal delivery, Controlled release, Hormone therapy

\begin{abstract}
This is an Open Access article that uses a funding model which does not charge readers or their institutions for access and distributed under the terms of the Creative Commons Attribution License (http://creativecommons.org/licenses/by/4.0) and the Budapest Open Access Initiative (http://www.budapestopenaccessinitiative.org/read), which permit unrestricted use, distribution, and reproduction in any medium, provided the original work is properly credited.
\end{abstract}

Tropical Journal of Pharmaceutical Research is indexed by Science Citation Index (SciSearch), Scopus, International Pharmaceutical Abstract, Chemical Abstracts, Embase, Index Copernicus, EBSCO, African Index Medicus, JournalSeek, Journal Citation Reports/Science Edition, Directory of Open Access Journals (DOAJ), African Journal Online, Bioline International, Open-J-Gate and Pharmacy Abstracts

\section{INTRODUCTION}

Norethisterone (NE) is a potent synthetic progestogen which is used for the treatment of dysfunctional bleeding by shifting the time of menstruation [1,2]. NE is absorbed rapidly and completely following oral administration, and it reaches maximal plasma levels within $1 \frac{1}{2} \mathrm{~h}$. Oral bioavailability of NE is about $64 \%$ due to the first pass metabolic effect. The half-life of NE is $8.0 \pm$
3.3 h. Being insoluble in water, NE is suitable for transdermal use because of its lipophilic nature [3-5].

Transdermal therapeutic systems (TTS) are developed for administration of drugs that have short plasma half-lives through the skin, so as to achieve controlled release. These systems minimize systemic side effects such as gastrointestinal (Gl) side effects of drugs when 
taken through the oral route. In addition, drugs can be avoided from the first pass metabolism, thereby increasing their bioavailability $[6,7]$. Another advantage is that trans-dermal drugs can be easily removed by the patient when necessary. TTS, can be prepared using either natural or synthetic polymers in membrane or matrix systems $[8,9]$.

To ease the penetration of drugs through the skin, penetration enhancers or fasteners may be added to the formulation [10]. TTS consists of non - permeable backing layer, drug reservoir, skin contact adhesive layer and a preventive membrane [11].

This study was aimed at preparing transdermal patches of NE for the first time, in order to overcome the side effects associated with oral administration of the drug.

\section{EXPERIMENTAL}

\section{Materials}

Norethisterone was purchased from Bayer (Turkey). Nitrocellulose membranes were from Millipore, while 3M 9773 Foam Tape, CoTran 9719 Backing and Scotchpak 1020 Release Liner were products of Drug Delivery Systems, Germany. Bio-Psa AC7-4201 was procured from Dow Corning Corp, Turkey. Carboxymethyl cellulose sodium, hydroxymethylcellulose and limonene were products of Merck (Turkey). Propylene glycol was bought from Doğa, Turkey, while Transcutolß was product of Gattefosse (France).

\section{Preparation of NE transdermal films and patches}

NE films were prepared with CMCNa and HEC (Table 1). Aqueous polymer was prepared under ultrasonic bath (Bersonic Turkey) and kept at room temperature for 24 hours. Then PG was added to the polymer gel and mixed using HS100D propeller mixer (Daihan Scientific, Korea) at $500 \mathrm{rpm}$. NE was dispersed in water (1:5) and mixed with gel - plasticizer mixture, with blending by propeller mixer at $500 \mathrm{rpm}$. The mixture was homogenously poured into a $9 \mathrm{~cm}$-diameter petri dish and dried inside a WiseVen Fuzzy Control System at $40 \pm 2{ }^{\circ} \mathrm{C}$ (Daihan Scientific, Korea). Limonene and Transcutol $\circledast$ were added to the liquid phase and films were prepared by the same method. NE transdermal patches (C-L, C$\mathrm{T}, \mathrm{H}-\mathrm{L}, \mathrm{H}-\mathrm{T}$ ) were prepared by using appropriate films. Films chosen were cut into $3.15 \mathrm{~cm}^{2}$ surface area pieces Transdermal patches were made by 3M 9773 Foam Tape, CoTran 9719 Backing, film, silicone skin contact adhesive (0.01 ml) (Bio-Psa AC7-4201) and Scotchpak 1020 Release Liner, as transdermal patch components (Table 1).

Table 1: Composition (\%) of NE transdermal films

\begin{tabular}{lcccccc}
\hline $\begin{array}{l}\text { Composition } \\
(\%)\end{array}$ & C & C-L & C-T & H & H-L & H-T \\
\hline CMC Na & 3 & 3 & 3 & - & - & - \\
HEC & - & - & - & 4 & 4 & 4 \\
PG & 7.5 & 7.5 & 7.5 & 10 & 10 & 10 \\
Transcutol $^{\circledR}$ & - & - & 5 & - & - & 5 \\
Limonen $_{\text {NE }}$ & - & 5 & - & - & 5 & - \\
\hline
\end{tabular}

Assessment of weight variation, thickness and tensile strength of films

Six different pieces $\left(1 \mathrm{~cm}^{2}\right)$ were carefully sliced from films and weighed. Their thickness were measured by a micrometer (Mitutoyo, Japan), and their tensile strengths were measured with Texture analyzer (TA - TX Texture Apparatus, U.K.). Determination was carried out under $200 \mathrm{~g}$ force with $5 \mathrm{~kg}$ loading chamber for 2s. Films of size $10 \times 80 \mathrm{~mm}$ were cut, with film length fixed at $40 \mathrm{~mm}$. Rotation speed of the probe were 1 $\mathrm{mm} / \mathrm{s}$ and $10 \mathrm{~mm} / \mathrm{s}$ at pre- and postmeasurement phases respectively. The test stage speed was $0.5 \mathrm{~mm} / \mathrm{s}$.

\section{Fourier transform infrared spectroscopy (FT - IR) analysis}

FT - IR (Perkin Elmer 100 FT - IR instrument, U.K.) was performed to determine the interaction between drug and transdermal film components. Adequate amounts of pure $\mathrm{NE}$ and $0.5 \mathrm{~cm}$ diameter film pieces were searched on a wave number between of 4000 to $650 \mathrm{~cm}^{-1}$ at resolution of $4 \mathrm{~cm}^{-1}$ in a FT-IR apparatus, at 100 $\mathrm{N}$ force.

\section{Determination of NE content of films}

The amounts of NE in the films were determined spectrophotometrically (Shimadzu UV - Visible Spectrophotometer UV - 1601, Japan) at 250 $\mathrm{nm}$.

Circular pieces $\left(1 \mathrm{~cm}^{2}\right)$ sliced films were dissolved in $10 \mathrm{ml}$ phosphate buffer solution $(\mathrm{pH}$ 7.4) containing $10 \%$ ethanol (dissolution medium) in the ultrasonic bath for $30 \mathrm{~min}$. 
Samples were diluted to $25 \mathrm{ml}$ and then filtered using blue ribbon filter $S \& S^{5893}$ papers.

\section{Validation of method of NE determination}

The spectrophotometric method was validated for linearity, intra - day and inter - day precision, accuracy, recovery and specificity. Absorption spectra of NE showed $\lambda$ max at $250 \mathrm{~nm}$ in dissolution medium. For this, $0.5-3 \mu \mathrm{g} / \mathrm{mL}$ standard NE solutions were prepared and assayed by suitable dilutions of $100 \mu \mathrm{g} / \mathrm{mL}$ stock NE solutions. Each study was replicated 6 times for linearity $[12,13]$. Precision of the method was shown as the relative standard deviation (RSD, $\%)$. Recovery (\%) was calculated based on the amount of drug found. Stability study was done to confirm variation of amount of NE with time.

\section{In vitro drug dissolution from films}

In vitro dissolution test for transdermal patches was carried out in accordance with the procedure reported in European Pharmacopoeiae in 2008. The test was performed on $4 \mathrm{~cm}$ pieces cut from films. Dissolution apparatus (Sotax AT - 7 Switzerland) was used with $900 \mathrm{~mL}$ of dissolution medium at $32 \pm 0.5^{\circ} \mathrm{C}$ and rotation speed of 50 $\mathrm{rpm}$. Samples were taken at pre-determined time intervals, diluted and assayed spectrophotometrically to determine their NE content. Release profiles were kinetically assessed by using zero order, first order, and Higuchi and Korsmeyer - Peppas models [14-16].

\section{In vitro drug release from transdermal patches}

Nitrocellulose membranes $(0.45 \mu \mathrm{m})$ were used between Franz - type diffusion cells (Çalışkan Cam, Turkey) with $3.15 \mathrm{~cm}^{2}$ surface area and $33.2 \mathrm{ml}$ receptor volume containing dissolution medium. The receptor phase was stirred with magnetic stirrer (WiseStir $\left.{ }^{\circledR} M S H ~-~ 20 A\right)$ at 600 $\mathrm{rpm}$ at $37 \pm 0.5^{\circ} \mathrm{C}$. Diffused amount of drug from patches was determined spectrophotometrically. Release profiles were assessed kinetically by
Higuchi and Korsmeyer - Peppas models [15,17]. Permeation coefficient $(P)$ of the membrane was evaluated as Eq 1.

$P=K \cdot H / A$

where $K$ is diffusion rate gained from the slope of the linear drug diffusion profiles, $H$ is the thickness of the film in $\mathrm{cm}$, and $A$ is the surface area of the film in $\mathrm{cm}^{2}$ [18].

The release rate of NE from patches was calculated by using cumulative amount of drug in $24 \mathrm{~h}$.

\section{Statistical analysis}

In vitro drug dissolution and release data were evaluated using GraphPad Prism 5 software to determine differences for profiles of all formulations at 0.05 as the level of significance.

\section{RESULTS}

\section{Weight variation, thickness, tensile strength and drug composition of films}

Results obtained from characterization studies, pharmaceutical quality of films and drug contents are shown in Table 2.

\section{FT-IR spectra}

FT-IR spectra of pure NE and its transdermal films are shown in Figures 1 and 2, respectively.

Characteristic bands of NE were detected at $3325.99 \mathrm{~cm}^{-1}$ (O - H stretching band), 1646.53 $\mathrm{cm}^{-1}(\mathrm{C}=\mathrm{O}$ carbonyl stretching band), 1614.60 $\mathrm{cm}^{-1}(\mathrm{C}=\mathrm{C}$ double bound stretching band), 2975.84 - $2833.94 \mathrm{~cm}^{-1}(\mathrm{C}-\mathrm{H}$ aliphatic stretching band), and $3271.08 \mathrm{~cm}^{-1}(\mathrm{C}=\mathrm{CH}$ triple bond acetylene stretching band). All the peaks between $1500-400 \mathrm{~cm}^{-1}$ are considered to be the finger print area of NE in Figure 1.

Table 2: Physical properties and NE contents of films

\begin{tabular}{lllll}
\hline Formulation & Weight $\mathbf{( m g )}$ & Thickness $(\mathbf{m m})$ & $\begin{array}{l}\text { Tensile strength } \\
\mathbf{( k g / s )}\end{array}$ & NE $(\mathbf{m g})$ \\
\hline C & $65.90 \pm 3.26$ & $0.33 \pm 0.002$ & $0.310 \pm 0.010$ & $1.10 \pm 0.01$ \\
C-L & $63.70 \pm 2.89$ & $0.32 \pm 0.002$ & $0.345 \pm 0.015$ & $1.11 \pm 0.01$ \\
C-T & $73.90 \pm 1.93$ & $0.43 \pm 0.002$ & $0.359 \pm 0.021$ & $1.19 \pm 0.01$ \\
H & $64.41 \pm 3.03$ & $0.34 \pm 0.003$ & $0.318 \pm 0.010$ & $1.13 \pm 0.01$ \\
H-L & $69.28 \pm 2.92$ & $0.37 \pm 0.004$ & $0.350 \pm 0.011$ & $1.15 \pm 0.02$ \\
H-T & $75.10 \pm 3.56$ & $0.47 \pm 0.004$ & $0.363 \pm 0.013$ & $1.23 \pm 0.02$ \\
\hline
\end{tabular}






Figure 1: FT - IR spectra of pure NE

In the spectrum of $\mathrm{C}$ - T film, the main bands of NE were detected with lower intensities as seen in Figure 2 (b). Bands related to the structure of $P G$ in the IR spectrum lost their sharpness. At $3351.18 \mathrm{~cm}^{-1}$ (O - H streching band), there was a broader PG peak. A broad peak $(\mathrm{O}-\mathrm{H}$ stretching band) was formed by Transcutol ${ }^{\circledR}$. The $\mathrm{C}-\mathrm{H}$ aliphatic streching band $(2974.61-2877.59 \mathrm{~cm}$ $\left.{ }^{1}\right)$ peak was not so sharp due to the effect of $P G$. The $\mathrm{C}=\mathrm{C}$ double bond streching band was observed at $1647.93 \mathrm{~cm}^{-1}$. Peaks belonging to NE skeletal structure were observable in the fingerprint area.

In the $\mathrm{H}$ - T film spectrum (Figure 2 (c)), the peaks of bands related to the structure of PG lost their sharpness. At $3345.23 \mathrm{~cm}^{-1}(\mathrm{O}-\mathrm{H}$ streching band), there was a broad $P G$ peak along with another peak close to it. Thus, the $\mathrm{C}=\mathrm{CH}$ triple bond acetylene streching band was within the band. Here, the $\mathrm{O}-\mathrm{H}$ streching band of Transcutol $\circledast$ was distinguishable. Compared with the other bands, the $\mathrm{O}-\mathrm{H}$ band was broader. Due to the influence of PG, $3007.59-2876.50 \mathrm{~cm}^{-1}$ band ( $\mathrm{C}-\mathrm{H}$ aliphatic streching band) was reduced in sharpness. The $\mathrm{C}=\mathrm{C}$ streching band $\left(1648.43 \mathrm{~cm}^{-1}\right)$ was observable, but the $\mathrm{C}=\mathrm{O}$ streching band was not observable because of the broadening of the other peak. The C-O stretching band (1537. $\left.35 \mathrm{~cm}^{-1}\right)$, which comes from Transcutol $\circledast$ was visible. Peaks belonging to NE skeletal structure were seen in the fingerprint area.

\section{Validation of spectrophotometric assay method}

In this method, the regression equation was as in Eq 2.

$y=0,0652 x+0,0016$

where $x$ is the concentration $(\mu \mathrm{g} / \mathrm{ml})$, and $y$ is the absorbance. The assay coefficient was $r^{2}=$ 0.9992 . The R.S.D. values gained from intra day and inter-day precision of the analytical method were between 0.5 - 1.74. R.S.D, and values from accuracy analysis were between 1.37 and 1.71 . The recovery of NE was between $98.45-99.69 \%$. Reagents such as the polymers and plasticizer did not absorb at $250 \mathrm{~nm}$, the wavelength of maximum absorbance for NE. From the calculations, it was found that concentration range of $0.98-1.01 \mu \mathrm{g} / \mathrm{ml}$, and R.S.D. values of $0.22-1.32 \%$ were adequate for the stability of NE.

\section{In vitro drug dissolution from films}

Films were integrated in the medium during the test period. The profiles obtained from the dissolution study are shown in Figure 3. The 


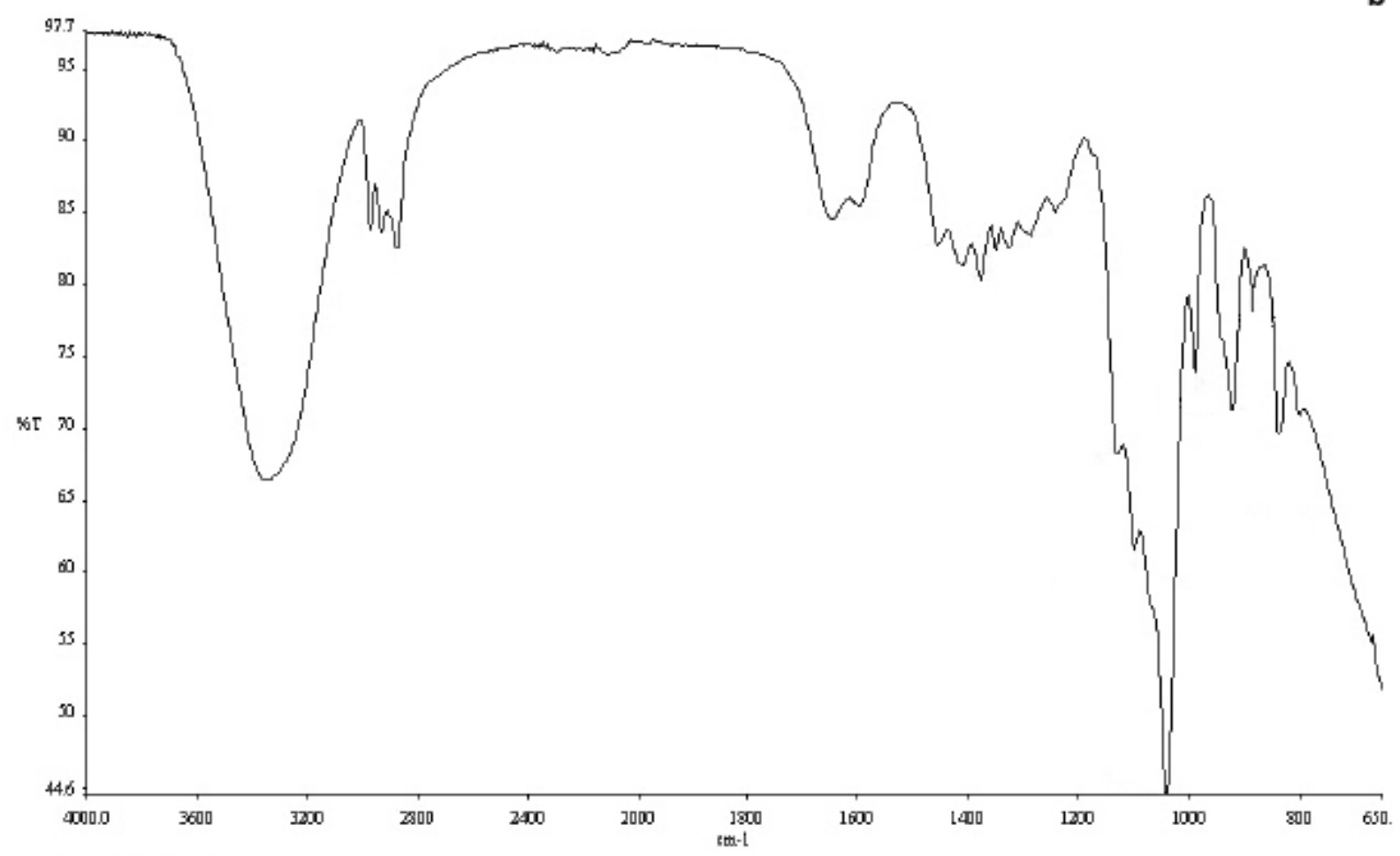

norothistheronesotshomithes

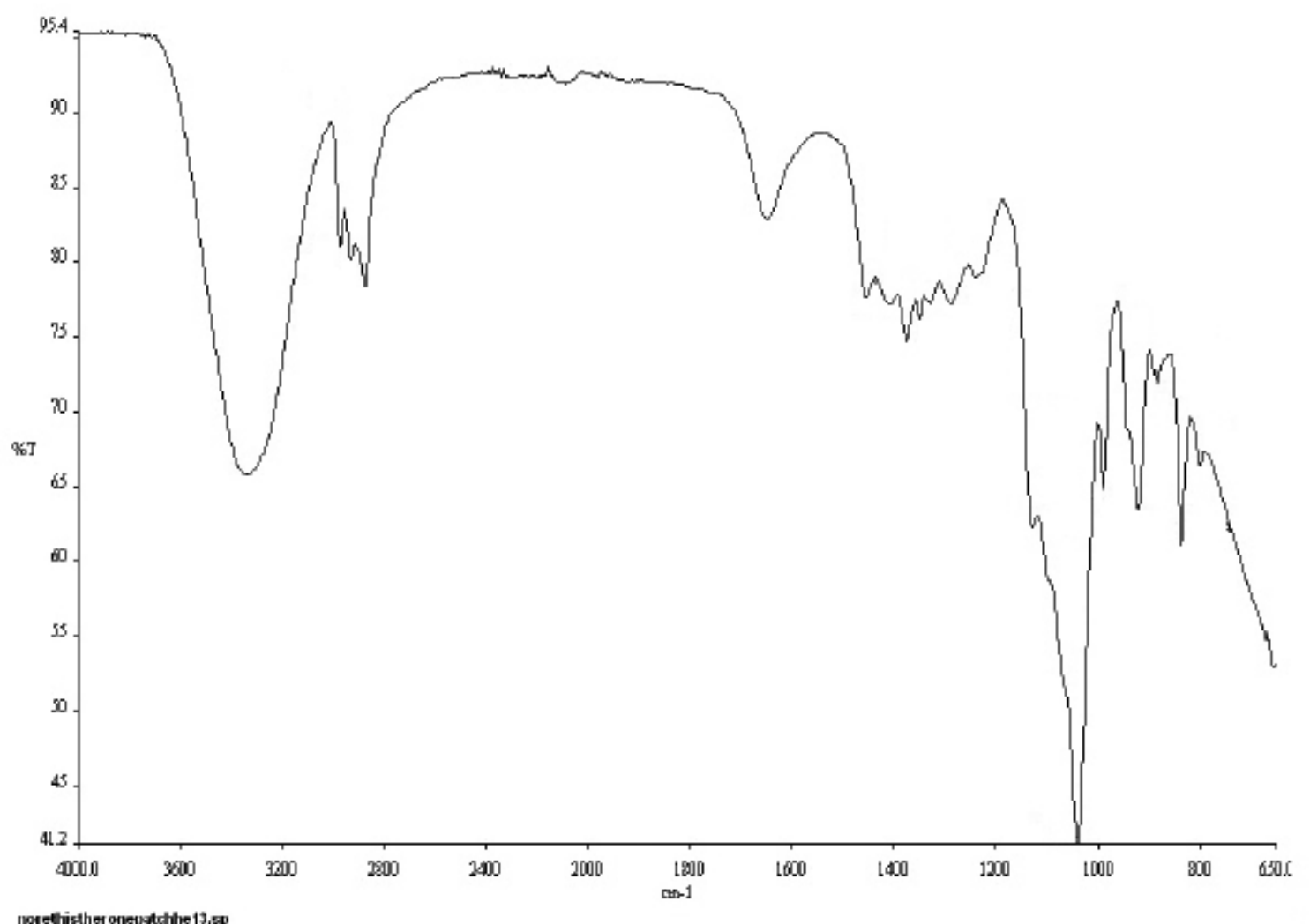

Figure 2: FT - IR spectra of C - T (b) and H - T (c)

amounts of drug dissolved at $8 \mathrm{hr}$ for C - T, C - L dissolution rates of the formulations within the and $\mathrm{C}$ were $42.79 \%, 36.18 \%$ and $35.12 \%$, same time frame $(\mathrm{p}>0.05)$. For the films, the respectively; and $60.04 \%, 55.43 \%$ and 54.18 highests amounts of drug dissolved at 8 th hour $\%$, respectively at $24 \mathrm{hr}$. There were no were $62.07 \%, 52.07 \%$ and $35.51 \%$; but at 24 statistically significant difference between the $\mathrm{hr}$, the amounts were $76.50 \%, 67.29 \%$ and 


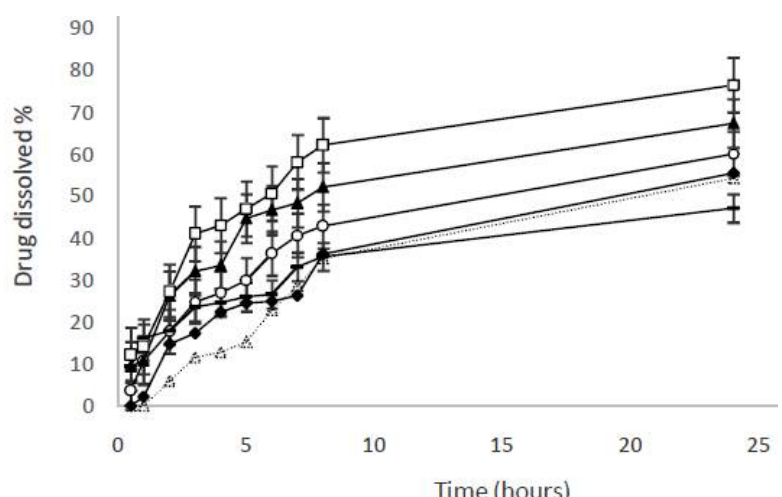

Figure 3: Dissolution profiles of NE films; ... .. = C, $\bullet-=\mathrm{C}-\mathrm{L},-\mathrm{O}-=\mathrm{C}-\mathrm{T},--=\mathrm{H},-\boldsymbol{\Delta}-=\mathrm{H}-\mathrm{L},--=\mathrm{H}-\mathrm{T}$

$47.05 \%$ for $\mathrm{H}-\mathrm{T}, \mathrm{H}-\mathrm{L}$ and $\mathrm{H}$, respectively. $\mathrm{H}$ $\mathrm{T}$ had higher dissolution rate than $\mathrm{H}(\mathrm{p}<0.05)$, while $\mathrm{H}-\mathrm{T}$ had higher dissolution rate than $\mathrm{C}$ and $C-L(p<0,05)$. Comparison of the drug release of the films showed that HEC (with $10 \%$ PG), had a higher drug release after $24 \mathrm{hr}$ than $\mathrm{CMCNa}$ with $7.5 \%$ PGs. All films showed Higuchi kinetics pointing out matrix formation. When Korsmeyer Peppas kinetics was evaluated, all the patches showed non-Fickian kinetics, excpt C - L (Table 3). Therefore, $\mathrm{H}$ - L, $\mathrm{H}-\mathrm{T}, \mathrm{C}-\mathrm{L}$, and $\mathrm{C}-\mathrm{T}$ were more suitable for incorporation into transdermal patches.

\section{In vitro drug release}

The result of transdermal patch drug release study from nitrocellulose membranes and the release profiles obtained are given in Figure 4. From this data, the amount of NE that diffused out from $C-T$ was higher than that from $C-L$. For $C-T$ and $C$ - $L$ patches, the calculated amount of NE released were $0.075 \mathrm{mg} / \mathrm{cm}^{2}$ and $0.052 \mathrm{mg} / \mathrm{cm}^{2}$ at the $8^{\text {th }}$ hour; and $0.136 \mathrm{mg} /$ $\mathrm{cm}^{2}$ and $0.112 \mathrm{mg} / \mathrm{cm}^{2}$ at the $24^{\text {th }}$ hour, respectively. Among the $\mathrm{CMCNa}$ patches, there were no statistically significant difference between the drug released $(p>0.05)$. The amount of NE that diffused out from $\mathrm{H}$ - T was higher than the amount that difused out from $\mathrm{H}$ L.

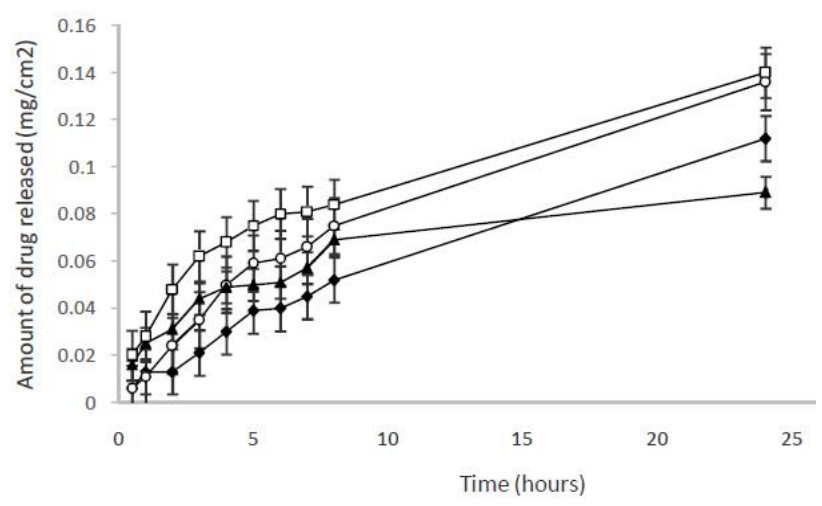

Figure 4: Release profile of NE from transdermal patches; $--=\mathrm{C}-\mathrm{L},-\mathrm{O}-=\mathrm{C}-\mathrm{T},-\boldsymbol{\Delta}-=\mathrm{H}-\mathrm{L},--=\mathrm{H}-$ $\mathrm{T}$

For $\mathrm{H}-\mathrm{T}$ and $\mathrm{H}-\mathrm{L}$ patches, NE release were $0.084 \mathrm{mg} / \mathrm{cm}^{2}$ and $0.069 \mathrm{mg} / \mathrm{cm}^{2}$ at $8 \mathrm{hr}$; and $0.140 \mathrm{mg} / \mathrm{cm}^{2}$ and $0.089 \mathrm{mg} / \mathrm{cm}^{2}$ at the $24 \mathrm{hr}$, respectively. However, in HEC patches, there were no statistically significant differences between the released amounts of drug ( $p>$ 0.05). Released drug was highest in $\mathrm{H}-\mathrm{T}$ followed by $C$ - $T$ when compared to $C-L$ patch $(p<0.05)$.

All patches displayed Higuchi kinetic model. When Korsmeyer Peppas kinetics was evaluated, all the patches displayed non-Fickian model except $\mathrm{H}$ - $\mathrm{L}$ (Table 3).

Table 3: Kinetic modeling of drug release from films and patches

\begin{tabular}{lcccccc}
\hline Formulation & $\begin{array}{c}\text { Zero } \\
\text { Order }\end{array}$ & $\begin{array}{c}\text { First } \\
\text { order }\end{array}$ & $\begin{array}{c}\text { Higuchi } \\
\text { model }\end{array}$ & $\begin{array}{c}\text { Exponential } \\
\text { (Korsmeyer - } \\
\text { Peppas model) }\end{array}$ & $\begin{array}{c}\text { Order of release } \\
\text { (Korsmeyer - } \\
\text { Peppas model) }\end{array}$ \\
\cline { 2 - 6 } & $\mathrm{r}^{2}$ & $\mathrm{r}^{2}$ & $\mathrm{r}$ & $\mathrm{r}^{2}$ & $\mathrm{n}$ & \\
\hline $\mathrm{C}$ & 0.9258 & 0.8105 & 0.9778 & 0.9593 & 0.9476 & $\mathrm{n} / \mathrm{a}$ \\
$\mathrm{C}-\mathrm{L}$ & 0.9155 & 0.6378 & 0.9811 & 0.8938 & 0.9231 & $\mathrm{n} / \mathrm{a}$ \\
$\mathrm{C}-\mathrm{T}$ & 0.8794 & 0.6662 & 0.9714 & 0.9599 & 0.7166 & NonFickian \\
$\mathrm{H}$ & 0.8842 & 0.7639 & 0.9747 & 0.9825 & 0.4052 & Fickian \\
$\mathrm{H}-\mathrm{L}$ & 0.8256 & 0.6724 & 0.9420 & 0.9603 & 0.5764 & NonFickian \\
$\mathrm{H}-\mathrm{T}$ & 0.8220 & 0.6771 & 0.9388 & 0.9604 & 0.5464 & NonFickian \\
Patches & & & & & & \\
$\mathrm{C}-\mathrm{L}$ & 0.9370 & 0.8241 & 0.9885 & 0.9866 & 0.7539 & NonFickian \\
$\mathrm{C}-\mathrm{T}$ & 0.9516 & 0.7313 & 0.9966 & 0.9855 & 0.8442 & NonFickian \\
$\mathrm{H}-\mathrm{L}$ & 0.8897 & 0.7580 & 0.9713 & 0.9854 & 0.4492 & Fickian \\
H-T & 0.9235 & 0.7605 & 0.9888 & 0.9876 & 0.5085 & NonFickian \\
\hline Note: $\mathrm{r}^{2}:$ determination coefficient; $n:$ release exponent; $n / a:$ not applicable &
\end{tabular}


The NE release rate from patches was highest with $\mathrm{H}-\mathrm{T}\left(0.0058 \mathrm{mg} / \mathrm{cm}^{2} / \mathrm{h}\right)$, followed by $\mathrm{C}-\mathrm{T}$, $\mathrm{C}-\mathrm{L}$ and $\mathrm{H}-\mathrm{L}$ with release rates of $0.0056 \mathrm{mg} /$ $\mathrm{cm}^{2} / \mathrm{h}, 0.0046 \mathrm{mg} / \mathrm{cm}^{2} / \mathrm{h}$ and $0.0037 \mathrm{mg} / \mathrm{cm}^{2} / \mathrm{h}$, respectively. In addition, permeability coefficients of the patches was highest for $\mathrm{H}-\mathrm{T}\left(4.55 \times 10^{-3}\right)$, followed by $C-T, C-L$ and $H-L$ with values of $4.02 \times 10^{-3}, 3.65 \times 10^{-3}$ and $2.50 \times 10^{-3}$, respectively.

\section{DISCUSSION}

The coefficient of the analytical method was $\mathrm{r}^{2}>$ 0.999 , which shows the linearity of the method. Precision was established by the R.S.D values in intra - day and inter - day NE analyses, with values lower than $2 \%$ in line with literature requirements [12]. The recovery values of $\mathrm{NE}$ were very good and appropriate at between 98.45 - $99.69 \%$. Moreover, there were no interferences in absorbance at $250 \mathrm{~nm}$ by the polymers and other formulation components used. This is proof of the specificity of the method. NE was stable during the solubility and drug delivery studies, as shown by the R.S.D values which were lower than $2 \%$. The results obtained in tests on the properties and pharmaceutical qualities of the NE films had low standard deviation values which satisfy the requirements for quality. The higher drug contents of films containing Transcutol ${ }^{\circledR}$ indicate that NE release was slower when the drug was formulated with this agent.

The strength of transdermal films is crucial in transdermal formulations. The physical strength and resistance of the films were acceptable, due to the fact that the qualities of PG [18] resulted in production of more flexible films. From the FT IR graphs, it was clear that the drug and film excipients were chemically compatible. Peaks belonging to NE skeletal structure were observed in fingerprint zones in all films [12]. Thus any changes in peaks must have occurred as a result of mixing of components and not due to any chemical interactions.

In this study, limonene and Transcutol ${ }^{\circledR}$ were used to ease drug release from the formulations. These compounds are generally recognized as safe (GRAS) by the FDA. Limonene and Transcutol $^{\circledR}$ not only form direct structural change on the skin, but also ease drug release from formulations [19]. Results of in vitro dissolution studies show that HEC films were of higher profiles during the first 24 hours than $\mathrm{CMCNa}$ films. $\mathrm{H}$, which did not contain penetration enhancers, showed lower dissolution results. The higher dissolution profiles of films containing penetration enhancers than films without them can be explained with the characteristics of Transcutol $^{\circledR}$ and limonen. Increases in the amount of PG in formulations resulted in higher drug release. This can be attributed to the synergistic action of $P G$ with penetration enhancers. In addition, the solubility of NE was $45.326 \pm 1.09 \mu \mathrm{g} / \mathrm{ml}$ in dissolution medium. This value indicates that the waterinsoluble NE can be dissolved sufficiently in the dissolution medium. In vitro drug release was higher in NE patches containing Transcutol ${ }^{\circledR}$ when compared to patches with limonene, indicating that Transcutol $^{\circledR}$ was more effective than limonene. Drug release from all films and patches displayed Higuchi kinetic model [15]. This strongly suggests that diffusion may be referred to drug release mechanism. The Fickian kinetic model indicates that a drug is released through diffusion mechanism, while the nonFickian kinetic model indicates that drug release occurs through a hybrid mechanism of diffusion / erosion [16,17].

\section{CONCLUSION}

NE transdermal patches containing HEC and 5 $\%$ Transcutol ${ }^{\circ}$ may be good candidates for enhanced skin penetration and delivery of NE. Thus, these patches can be further developed as an alternative to the oral route of administration of this drug to improve patient compliance.

\section{DECLARATIONS}

\section{Acknowledgement}

This article was generated from the MSc thesis of Dilek Şaki, Istanbul University, 2011. Authors also would like to thank Dr Aslı Barla for helping to interprete the FT-IR results.

\section{Conflict of interest}

No conflict of interest is associated with this work.

\section{Contribution of Authors}

The authors declare that this work was done by themselves and all liabilities pertaining to claims relating to content of this article will be borne by them.

\section{REFERENCES}

1. Stanczyk FZ. All progestins are not created equal. Steroids 2003; 68(10-13):879-890.

2. Roxburgh DR, West MJ. The use of norethisterone to 
suppress menstruation in the intellectually severely retarded woman. Med J Aust 1973; 2(7): 310-313.

3. Back DJ, Breckenridge AM, Crawford FE, Mciver M, Orme ML, Rowe PH, Smith E. Kinetics of norethindrone in women. II. Single-dose kinetics. Clin Pharmacol Ther 1978; 24:448-453.

4. Edelman AB, Cherala G, Stanczyk FZ. Metabolism and pharmacokinetics of contraceptive steroids in obese women: a review. Contraception 2010; 82: 314-323.

5. Ghoneima MM, Abushoffab AM, Moharrama YI, ElDesokya HS. Voltammetry and quantification of the contraceptive drug norethisterone in bulk form and pharmaceutical formulation. J Pharm Biomed Anal 2007; 43: 499-505.

6. Brown MB, Martin GP, Jones SA, Akomeah FK. Dermal and transdermal drug delivery systems: current and future prospects. Drug Delivery 2006; 13: 175-187.

7. Williams AC. Transdermal and topical drug delivery from theory to clinical practice. Pharmaceutical Press, London, 2003.

8. Baker RW, Heller J. Materials selection for transdermal delivery systems. STS Publishing, U.K, 1992.

9. Valenta C, Auner BG. The Use of polymers for dermal and transdermal delivery. European $\mathrm{J}$ of Pharmac and Biopharm 2004; 58: 279-289.

10. Woodford R, Barry BW. Penetration enhancers and the percutaneous absorption of drugs: an update. $J$ Toxicol Cut \&Ocular Toxicol 1986; 5: 167-177.

11. Van Buskirk GA, et al. Scale-up of adhesive transdermal drug delivery systems. Pharm Res 1997; 14: 848-852
12. USP 31, 26 Edition, Council of experts and published by the board of trustees, validation of compendial procedures. 20852 Twinbrook Parkway Rockwille, 2008.

13. ICH Harmonised Tripartite Guideline. Validation of analytical procedures: text and methodology Q2 (R1) 2005. International Conference on Harmonisation of Technical Requirements for Registration of Pharmaceutıcals for Human Use

14. The European Pharmacopoeia 6th Edition, Council of Europe, France, 2008

15. Higuchi T. Mechanism of sustained-action medication. Theoretical analysis of rate of release of solid drugs dispersed in solid matrices. J Pharm Sci 1963; 52: 11451149.

16. Korsmeyer RW, Gurny R, Doelker E, Buri P, Peppas NA. Mechanisms of potassium chloride release from compressed, hydrophilic, polymeric matrices: effect of entrapped air. J Pharm Sci 1983; 72(10): 1189-1191.

17. Vueba ML, Pina ME, Veiga F, Sousa JJ, Batista de Carvalho LAE. Conformational study of ketoprofen by combined DFT calculations and Raman spectroscopy. Int J Pharm 2006; 307; 56-65.

18. Rao PR, Diwan PV. Permeability studies of cellulose acetate free films for transdermal use: Influence of plasticizers Pharm Acta Helv 1997; 72: 47-51.

19. Aqil M, Ahad A, Sultana J, Ali A. Status of terpenes as skin penetration enhancers. Drug Discov Today 2007; 12(23-24): 1061-1067. 